\title{
"UN-HATCHING" FEDERAL EMPLOYEE POLITICAL ENDORSEMENTS
}

\author{
William L. Magness $\dagger$
}

Kenneth T. Blaylock is the president of the American Federation of Government Employees (AFGE), a federal employees' union. He has been a federal employee since 1954, but has been on leave without pay $^{1}$ since 1972 in order to work for the union full-time, first as the president of an AFGE local in Alabama and, since 1976, as the national AFGE president. ${ }^{2}$ As the leader of one of the nation's larger federal employee unions-AFGE has approximately 200,000 members ${ }^{3}$ in 1500 locals - Blaylock often speaks publicly and lobbies Congress on federal personnel issues. ${ }^{5}$

Since 1981, Blaylock and other federal union leaders have attacked the personnel policies of the Reagan administration. ${ }^{6}$ Sensing the administration's unwillingness to change these policies and having suffered legislative defeats at the hands of the President and his allies, ${ }^{7}$ the AFGE endorsed the 1984 presidential candidacy of Walter Mondale,

†B.A. 1984, University of Texas; J.D. Candidate 1987, University of Pennsylvania.

1 Leave without pay status allows federal employees to remain part of the federal retirement system and to maintain membership in employee life and health insurance plans. Leave without pay is approved by the department for which the employee works-in Blaylock's case by the Department of the Air Force. Telephone interview with Sandra Adams-Choate, Staff Attorney with the American Federation of Government Employees (Oct. 10, 1985).

2 Joint Stipulation of Facts at 1-2, Special Counsel v. Blaylock, No. HQ12068510017 (M.S.P.B. Oct. 22, 1985).

3 Id. at 5 . 1985).

11985 EnCyclopedia of Associations $\S 15$, at para. 17590 (D. Akey ed.

B Blaylock writes a monthly column in the AFGE newsletter, The Government Standard, in which he discusses "issues or subjects that interest, concern, or affect" AFGE members. Joint Stipulation of Facts, supra note 2, at 5. He was cited by President Carter as one of the key lobbyists in the effort to pass civil service reform in 1978. See Remarks at Signing of Civil Service Reform Act of 1978, 14 Weekly Comp. Pres. Doc. 1761, 1764 (Oct. 13, 1978). On the lobbying efforts of AFGE and other federal employee unions, see Masters, Federal Employee Unions and Political Action, 38 INDUS. \& LAB. REL. REv. 612 (1985).

- See, e.g., Federal Unions Gain Members as Fear of What Reagan Will Do Next Increases, 928 Gov't Empl. Rel. Rep. (BNA) 5 (Sept. 7, 1981); Several Hundred AFGE Workers March to Protest Reagan Budget Cuts, RIFs, 921 Gov't Empl. Rel. Rep. (BNA) 8 (July 20, 1981).

7 See, e.g., Masters, supra note 5, at 620-26 (discussion of the legislative record). 
as did several other federal employee unions. ${ }^{8}$ In various speeches and in his column in the AFGE's national newsletter Blaylock vehemently assailed Reagan administration policies and urged AFGE members to vote for Mondale and to contribute to the union's political action committee. ${ }^{9}$ In November 1984 , Mondale was soundly defeated by President Reagan.

In February 1985, the Office of Special Counsel, the prosecution arm of the Merit Systems Protection Board, ${ }^{10}$ filed charges against Blaylock, as well as against Morris Biller, president of the American Postal Workers Union, and Vincent R. Sombrotto, president of the National Association of Letter Carriers. ${ }^{11}$ They were accused of violating the Hatch Act, ${ }^{12}$ a 1939 statute restricting the political activity of federal employees. The Special Counsel claimed that the union leaders-all of whom were federal employees on leave without pay ${ }^{13}$ - violated the Act's prohibitions against endorsing and soliciting support for partisan political candidates. ${ }^{14}$ In October 1985, a Merit Systems Protection Board administrative law judge found Blaylock, Biller, and Sombrotto guilty of violating the Hatch Act and recommended penalties for each offender. ${ }^{15}$

Some observers found the prosecutions of Blaylock, Biller, and Sombrotto surprising. ${ }^{16}$ Federal employee union officials had endorsed candidates in previous presidential elections ${ }^{\mathbf{1 7}}$ and appeared to have, at

${ }^{8}$ See Bierman \& Masters, The Need for Hatch Act Clarification, 36 LAB. L.J. 313, 317 (1985).

- For examples of Blaylock's editorials during the 1984 campaign, see Complaint for Disciplinary Action at Attachments 6-8, Special Counsel v. Blaylock, No. HQ12068510017 (M.S.P.B. Oct. 22, 1985).

10 See Bierman \& Masters, supra note 8, at 317. The Merit Systems Protection Board is the successor to the Civil Service Commission and, as such, took over the Commission's Hatch Act duties.

11 See Three Union Chiefs Face Prosecution, Washington Post, Feb. 13, 1985, at A1, col. 1 .

12 The union leaders were charged with violating the Hatch Act's prohibition on employees taking "an active part in political management or in political campaigns." 5 U.S.C. $\$ 7324(\mathrm{a})(2)$ (1982). The Act is currently codified as amended at 5 U.S.C. $\S \S 1501-1503,7324-7327$ (1982 \& Supp. III 1985) and at 18 U.S.C. $\$ \S 594,595$, $598,600,601,604,605$ (1982). The Act's provisions are discussed in detail infra notes 24-75 and accompanying text.

1s See Sinzinger, No Free Speech for Federal Unions, 240 Nation 482, 489 (1985).

14 See Complaint for Disciplinary Action at 1-5, Special Counsel v. Blaylock, No. HQ12068510017 (M.S.P.B. Oct. 22, 1985).

${ }^{15}$ See Schwartz, Suspensions Urged for Three Union Presidents, Washington Post, Oct. 23, 1985, at A21, col 1.

${ }_{16}$ See, e.g., Bierman \& Masters, supra note 8, at 317. ("This OSC action is surprising, largely because partisan endorsements from union officials on leave from their federal jobs are hardly a new occurrence.").

17 A coalition of federal employee unions endorsed Jimmy Carter in the 1976 
least de facto, the right to such political expression..$^{18}$ Legally, however, the prosecutions are valid applications of the Hatch Act's prohibitions on employee endorsements of partisan political candidates. As it has been interpreted and applied, the Hatch Act clearly prohibits advocacy for or against partisan political candidates. ${ }^{19}$

This Comment argues that the provisions of the Hatch Act prohibiting such endorsements should be repealed. While some of the Act's limits on federal employee political activity may be justified by the government's interest in the fair and efficient administration of the law, restrictions on endorsements are unnecessary and unfair limits on the expression of employee political interests. These restrictions deny employee organizations their place in debates campaigns in which the outcome will often determine employee rates of pay and conditions of employment. Denied effective economic bargaining power by statute, ${ }^{20}$ federal employee groups should be allowed to advocate changes through the electoral process. An amendment to the Hatch Act, lifting the statute's proscription of endorsements, would give employee groups a meaningful opportunity to participate in political debate.

Part I of this Comment surveys the history and application of the Hatch Act, focusing primarily on the Act's treatment of employee political endorsements. Part II discusses the relevancy of government interests in employee political activity restrictions, as identified by the United States Supreme Court in Civil Service Commission v. National Association of Letter Carriers, ${ }^{21}$ to limits on employee group endorsements. Part III examines the detrimental effects of endorsement prohibitions on employee interests in participating in partisan debate and concludes that these prohibitions should be repealed.

Before proceeding further, however, a definition and two prelimi-

presidential election. See OSC Accuses Three Union Chiefs of Unlawful Political Activity, 23 Gov't Empl. Rel. Rep. (BNA) 212, 213 (Feb. 18, 1985). Several federal employee unions endorsed Carter's reelection in 1980, whereas the Professional Air Traffic Controllers' Organization backed Ronald Reagan. See Sinzinger, supra note 13, at 429.

18 See Masters, supra note 5, at 617 (footnote omitted) ("[T]he [federal employee] unions have undoubtedly acquired and exercised the de facto right to engage in certain partisan activities, such as endorsing Democratic candidates . . . .").

${ }^{19}$ See 5 C.F.R. \$ 733.122(b)(10) (1986) (")(b) [Prohibited political] [a]ctivities ... include but are not limited to - . . (10) Endorsing or opposing a candidate for public office in a partisan election or a candidate for political party office . . . .").

${ }^{20}$ Federal employee unions' collective bargaining rights are extensively circumscribed by statute. The range of permissible subjects of bargaining is narrow and employees are prohibited from striking. The extent of federal union collective bargaining rights is discussed infra notes 190-200 and accompanying text.

${ }_{21}^{21} 413$ U.S. 548 (1973). In Letter Carriers the Court rejected a claim by federal employees and an employees' union that the restrictions imposed by $\S 9$ (a) of the Hatch Act were unconstitutionally vague and overbroad. 
nary observations are in order. As used in this Comment, an "endorsement" constitutes a public expression of support for a political candidate, usually accompanied by an exhortation to others to vote for the favored candidate. An endorsement is partisan advocacy; it does not, in itself, include physical participation in a campaign. In a pluralistic political process, endorsements are part of the give and take between candidates and competing interest groups. By identifying the candidates who will best pursue a group's interests, endorsements inform both a group's members and its supporters that a vote for an endorsed candidate is, in effect, a vote to further the group's interests. ${ }^{22}$ While group endorsements may take a more active form, such as providing money and human resources for a candidate's campaign, this Comment is concerned only with protecting endorsements that serve the functions of education and advocacy without involving federal employees in the actual mechanics of campaign management.

The first preliminary observation concerns this Comment's use of the term "employee union" and "employee group." The terms are used interchangeably because although unions are the federal employee organizations that may be expected to make endorsements most frequently, the rationale for abandoning Hatch Act restrictions applies to all groups organized to advocate on behalf of federal employees. When the AFGE endorses candidate Doaks, a nonunion group with different views should be free to endorse candidate Cooley. This Comment's analysis of employee interests and endorsements is not limited to the union context, and neither is its terminology.

Second, although first amendment interests are obviously implicated by government restrictions on political activity, this Comment does not attack the constitutionality of the Hatch $\mathrm{Act}^{23}$ but instead argues that the restrictions on political endorsements currently imposed by the Act do not in fact further the policies the Act was intended to advance.

22 Personal endorsements that do not include promises of campaign funding or volunteers are usually worth only the credibility they confer on the endorsed candidate. See L. Sabato, The Rise of Polmtical Consultants 217 n.279 (1981).

2s Several commentators argue that Hatch Act restrictions on employee speech and activity violate the first amendment. See e.g., R. Dwoskin, Rights of THE PUBlic EMPloyee 143-47 (1978); T. EMERSON, The SySTEM of FreEdom of ExpresSION 563-92 (1970); Martin, The Constitutionality of the Hatch Act: Second Class Citizenship for Public Employees, 6 U. ToL. L. REv. 78 (1974); Note, Restrictions on Political Activities of Government Employees, 87 W. VA. L. REV. 165 (1984). 


\section{The Meaning of Hatch Act Political Activity RESTRICTIONS}

\section{A. A Brief History of the Hatch Act ${ }^{24}$}

The Hatch Act ${ }^{26}$ was passed in 1939 in response to congressional fears that the federal service, which was rapidly growing due to the New Deal expansion in the role of government, was being used to coerce support of Roosevelt administration policies. ${ }^{28}$ The statute was not the first attempt to restrict the political activities of federal employees; Thomas Jefferson, in 1801, was the first to call for employee political neutrality, ${ }^{22}$ and subsequent Presidents issued a series of executive orders placing various restrictions on employees in the competitive civil service. ${ }^{28}$ These restrictions were set out in section 1 of Civil Service Rule I. ${ }^{29}$ The Civil Service Commission, charged with enforcing Civil

34 For more comprehensive discussions of the history of the Hatch Act, see Rose, A Critical Look at the Hatch Act, 75 HARv. L. REv. 510 (1962); Vaughn, Restrictions on the Political Activities of Public Employees: The Hatch Act and Beyond, 44 Geo. WASH. L. REV. 516 (1976).

${ }_{25}$ Hatch Act, Pub. L. No. 76-252, 53 Stat. 1147 (1939) (codified as amended at 5 U.S.G. $\S \S 1501-1503,7324-7327$ (1982 \& Supp. III 1985); 18 U.S.C. $\S \S 594,595$, $598,600,601,604,605(1982))$. The statute takes its popular name from its sponsor, Senator Hatch of New Mexico. The title of the legislation was: "An act to prevent pernicious political activities." Id. The Act was amended in 1940. The amendments extended Hatch Act political activity restrictions to state and local government employees who work in federally funded programs. See Act of July 19, 1940, Pub. L. No. 76753, $\S 4,54$ Stat. 767 (codified as amended at 5 U.S.C. $\S 1502$ (1982)). These restrictions were modified in 1974. Currently, state and local government employees affiliated with federal programs are prohibited only from becoming candidates for partisan office. See 5 U.S.C. $\$ \S 1502,1503$ (1982); 5 C.F.R. $\$ \S 151.111-.122$ (1986); see also Roumell, Protection of the Integrity of Each Party from Domination by the Other, in The Evolving Process-Collective Negotiations in Public Employment 370, 385 (J. Lefkowitz ed. 1985) (describing changes in Hatch Act restrictions on state and local government employees). Other sections of the 1940 amendments affected the definition of prohibited political activities. These proyisions are discussed infra notes 35-41 and accompanying text.

${ }^{26}$ See Roumell, supra note 25, at 380; Vaughn, supra note 24, at 518.

27 See Vaughn, supra note 24 , at 517.

28 See id. at 517-18.

29 Section 1 of Civil Service Rule I, at the time the Hatch Act was passed, provided:

No person in the executive civil service shall use his official authority or influence for the purpose of interfering with an election or affecting the results thereof. Persons who by the provisions of these rules are in the competitive classified service, while retaining the right to vote as they please and to express their opinions on all political subjects, shall take no active part in political management or in political campaigns.

Civil Service Rule I, § 1, reprinted in U.S. Givil Service Commission, 2 Political Activity Reporter [P.A.R.] 3 (1972). In 1907, President Roosevelt issued Executive Order 642, which was incorporated into Civil Service Rule I. See Rose, supra note 24, at 510. It was this executive order that first added restrictions on taking an active part in 
Service Rule I, applied the terms of the executive orders to particular cases, thereby creating a body of case law consisting of over 3000 civil service rulings. ${ }^{30}$

When Congress passed the Hatch Act in 1939, section 9(a) was virtually a restatement of these civil service rulings. ${ }^{31}$ The prohibition against corrupting the electoral process stirred little controversy. The use of federal power to interfere with the conduct of elections or to coerce voters dependent upon government benefits or jobs was seen as a threat to the integrity of the growing federal service..$^{32}$ Moreover, the prevention of political coercion has been a key element in all civil service reform since the 1883 Civil Service Act. ${ }^{33}$ The second provision of section 9(a), however, raised a serious problem. The statutory term "active part in political management or in political campaigns," which was inherited from Civil Service Rule I, did not carry a generally understood objective meaning.

This definitional problem was addressed in the 1940 amendments to the Act. ${ }^{34}$ The 1940 amendments included three additions to the stat-

political management or in political campaigns. See Civil Service Rule I, supra; see also Rose, supra note 24, at 510 (quoting President Roosevelt's 1907 amendment to Civil Service Rule I).

so See Rose, supra note 24 , at 511.

31 Section 9(a) of the Hatch Act as enacted in 1939 stated:

It shall be unlawful for any person employed in the executive branch of the Federal Government, or any agency or department thereof, to use his official authority or influence for the purpose of interfering with an election or affecting the result thereof. No officer or employee in the executive branch of the Federal Government, or any agency or department thereof, shall take any active part in political management or in political campaigns. All such persons shall retain the right to vote as they may choose and to express their opinions on all political subjects.

Act of August 2, 1939, Pub. L. No. 76-252, 53 Stat. 1147, 1148 (codified as amended at 5 U.S.C. $\S 7324$ (1982)). Compare the language of $\S 9(a)$ with that of Civil Service Rule I. See supra note 29. The Hatch Act's Senate report called § 9(a) "a restatement of the law now in effect as regards civil-service employees." S. REP. No. 221, 76th Cong., 1st Sess. 2 (1939).

${ }_{32}$ The most immediate congressional concern was that the Works Progress Administration (WPA) was being manipulated politically. See Martin, supra note 23, at 84-86. Reports of political coercion of WPA participants by federal administrators stirred the debate regarding political activity restrictions that resulted in the passage of the Hatch Act. See, e.g., 83 Cong. REc. 7970-8000 (1938) (debate concerning necessity for cutting off federal salaries for employees who coerced WPA participants). When the Hatch Act was passed in 1939, many legislators viewed the removal of politics from New Deal programs as its most important legislative objective. See, e.g., 84 CoNG. REC. 10,747 (1939) (statement of Sen. Austin) ("The important fact is that we have now in effect a law which denounces the misuse or abuse of charity or relief .....").

ss The goals of civil service reform and the merit system are discussed infra notes 91-114 and accompanying text.

s4 Act of July 19, 1940, Pub. L. No. 76-753, 54 Stat. 767 (codified as amended at 
ute that attempted to clarify the scope of section 9(a) political activity proscriptions. An amendment to section 9 (a) made it clear that employees retained their rights to express opinions about political candidates as well as about abstract political issues. ${ }^{35}$ Second, the 1940 legislation added section 18, which allows employees to participate in nonpartisan municipal elections or campaigns for or against a referendum or constitutional amendment. ${ }^{36}$ Third, and most important, was the addition of section 15, which provides a definition for the political activities prohibited by section 9(a). The Hatch Act provisions prohibiting employees from participating in political activity are

deemed to prohibit the same activities .... as the United States Civil Service Commission has heretofore determined are at the time this section takes effect prohibited ... by the provisions of the civil-service rules prohibiting . . . employees from taking any active part in political management or in political campaigns. ${ }^{37}$

By defining the section 9(a) prohibitions in terms of prior Civil Service Commission rulings, Congress adopted the restrictions that the Commission had placed on the activities of competitive civil service employees through its adjudications of Civil Service Rule I. ${ }^{38}$ The meaning of these restrictions was elaborated through further adjudications of rule I cases and by summaries of permitted and prohibited activity issued periodically by the Civil Service Commission. ${ }^{38}$ Thus, in order to

5 U.S.G. $\S \S 1501-1503,7324-7327$ (1982 \& Supp. III 1985); 18 U.S.G. $\S 594,595$, $598,600,601,604,605(1982))$.

ss Act of July 19, 1940, $\$ 2,54$ Stat. at 767 (codified as amended at 5 U.S.C. $\S 7324$ (b) (1982)) (amending $\S 9$ (a) to ensure federal employees the "right . . . to express their opinions on all political subjects and candidates").

se Act of July 19, 1940, $\$ 4,54$ Stat. at 772 (codified as amended at 5 U.S.C. $\S 7326$ (1982)) (preventing $\S 9$ (a) from prohibiting "political activity . . . in connection with any question which is not specifically identified with any National or State political party").

${ }^{37}$ Act of July $19,1940, \S 4,54$ Stat. at 771 (codified as amended at 5 U.S.C. $\S 7324$ (1982)). In 1942 the language "at the time this section takes effect" was changed to "July 19, 1940," the date of the passage of the 1940 amendments. This date remains part of the current statutory language. See 5 U.S.C. § 7324(a) (1982).

${ }^{38}$ See Rose, supra note 24, at 513-14.

30 Prior to the passage of the Hatch Act, the Civil Service Commission informed employees of their rights under Civil Service Rule I by periodically issuing pamphlets listing permitted and prohibited activities. The activities listed in the pamphlets were those that the Commission found to violate the Civil Service Rule in its adjudications of political activity cases. The pamphlets were brief and contained incomplete summaries of Civil Service Rule I violations. See id. at 511. The pamphlet in use at the time of the Hatch Act debates was designated "Form 1236." Form 1236 is reproduced as an appendix to the United States Supreme Court's opinion in Civil Serv. Comm'n v. Nam tional Ass'n of Letter Carriers, 413 U.S. 548, $581-95$ (1973). 
understand the substance of section 9(a) prohibitions, one must become familiar with the Civil Service Commission's policy of interpreting and enforcing political activity rules under the executive orders and Commission rules issued between 1883, the date of the Civil Service Act, and July 19, 1940, the date of the Hatch Act amendments. ${ }^{40}$

Several considerations make this historical incorporation approach to defining prohibited political activity troublesome. First, the pre-1940 Commission decisions are not readily available. ${ }^{41}$ Many were not published, and, among those that were, several are simply lists of offending employees and the penalties levied for their transgressions. ${ }^{42}$ Second, a substantial number of the more than 3000 decisions merely provide vague statements of the standards by which violations were found. ${ }^{43}$ Third, the Civil Service Commission was not granted rulemaking power to adjust or further interpret the terms of the statute. ${ }^{44}$ In refusing to give the Commission flexibility in interpreting the Hatch Act, Congress left the statutory definitions frozen as they were in $1940 .{ }^{45}$

Despite the difficulties in determining the parameters of the pre1940 restrictions, the political activity definition established in the 1940 amendments survived constitutional challenge in a 1973 Supreme Court decision, Civil Service Commission v. National Association of Letter

40 In an attempt to address the confusion regarding Civil Service Commission definitions of political activity, Senator Hatch read Form 1236 into the Congressional Record. See 86 Cong. REc. 2938-40 (1940). Nevertheless, during the 1940 debates several senators expressed concern that none of the legislators knew the content of the rulings they were incorporating into the Act. See, e.g., 86 CoNG. REC. 2940 (1940) (remarks of Sen. Minton) ("No one on the floor of the Senate, not even the Senator from New Mexico [Sen. Hatch], now knows what these rules and regulations are.").

11 See Rose, supra note 24, at 522-25.

42 See National Ass'n of Letter Carriers v. Givil Serv. Comm'n, 346 F. Supp. 578, 580-81 (D.D.C. 1972) (discussing ambiguities in the definition of prohibited activities), rev'd, 413 U.S. 548 (1973). Even the post-1940 Commission decisions were not easily accessible until the Commission's 1971 publication of the Political Activity Reporter (P.A.R.). See Note, supra note 23, at 170.

${ }^{43}$ See Rose, supra note 24, at 523 ("Many of the decisions that are available may be less than enlightening .....").

4 The original version of the 1940 legislation gave the Civil Service Commission rulemaking power to elaborate the terms of $\S 9$ (a). See S. REP. No. 1236, 76th Cong., 3d Sess. 2 (1940). In offering the floor amendment which ultimately became $\S 15$, Senator Hatch said, "[I]t seemed to me to be very wise not to give the Commission any more power to interpret further in the future." 86 CoNG. REC. 2949 (1940).

45 See Rose, supra note 24, at 525 (footnote omitted):

The freezing of precedent decisions into doctrinaire rules to control decision of future cases is at odds with our adjudicatory tradition, is unsound, and is unworkable. The attempt of Congress to establish such a rigid precedent system by section 15 was doomed from the start . . . . The road to a fair balance of competing interests cannot be navigated with only a rear view mirror. 
Carriers. ${ }^{48}$ Although the lower court found that statute "impermissibly vague and overbroad" 47 in its limitations on the first amendment rights of public employees, the Supreme Court found the Commission's various summaries and restatements of what was allowed under Civil Service Rule I clear enough to save the statute. ${ }^{48}$ The Court held that Congress intended to adopt the Civil Service Commission's 1940 restatement of forbidden activity as the definition of "active part in political management and political campaigns" ${ }^{\prime 49}$ and found that the 1970 regulations comprising the restatement ${ }^{\text {s0 }}$ were "wholly legitimate descendants of the 1940 restatement adopted by Congress and were arrived at by a process that Congress necessarily anticipated would occur down through the years." 81 The 1970 restatement was, in effect, read into the text of the Hatch Act by the Letter Carriers Court, ${ }^{\mathbf{} 2}$ which found that the statute's prohibitions, as defined in the 1970 restatement, presented no constitutional vagueness or overbreadth problems. ${ }^{83}$ The substance of Hatch Act restrictions are thus still found in the lists of permitted and prohibited activities upheld in Letter Carriers and the adjudicatory decisions of the Civil Service Commission and its successor, the Merit Systems Protection Board. ${ }^{\text {.4 }}$

\section{B. Application of the Hatch Act}

The "nebulous statutory proscription"ss against taking "an active

16 413 U.S. 548 (1973). See infra notes 76-90 and accompanying text for a more detailed discussion of the Letter Carriers decision.

47 National Ass'n of Letter Carriers v. Civil Serv. Comm'n, 346 F. Supp. 578, 585 (D.D.C. 1972), rev'd., 413 U.S. 548 (1973).

48 See 413 U.S. at 568-81.

10 Id. at 575 .

so See 5 C.F.R. §§ 733.101-.124 (1986).

81413 U.S. at 575.

82 See id.; see also American Postal Workers v. United States Postal Serv., 764 F.2d 858, 862-63 (D.C. Cir. 1985), cert. denied, 106 S. Ct. 792 (1986) (following and explaining the Letter Carriers interpretation of the $\S 15$ political activity definition).

ss See 413 U.S. at 581.

54 The Civil Service Commission was abolished by the Civil Service Reform Act of 1978, Pub. L. No. 95-454, 92 Stat. 1111 (codified in scattered sections of 5, 10, 15, 28, 38, 39, and 42 U.S.C. (1982)). For a listing of the several sections of the U.S.C. in which the Act is codified, see Tables U.S.C. table III, 1020-23 (1982). The Merit Systems Protection Board took over the Commission's Hatch Act responsibilities. The Office of Special Counsel, an independent investigative and prosecutorial arm of the Merit Systems Protection Board, prosecutes political activity cases. See 5 U.S.C. $\S 1206(\mathrm{e})(1)(\mathrm{A})$-(B) (1982). For a survey of the workings of the Merit Systems Protection Board and Office of Special Counsel, see R. Vaughn, Merit Systems ProtecTION BoARD: Rights and Remedies (1984). See generally OfFice of Special Counsel, A Report to Congress from the Office of Special Counsel, Fiscal YEAR 1984 (1984) (describing the operations of the Office of Special Counsel).

os Developments in the Law-Public Employment, 97 HARv. L. REv. 1611, 1652 
part in political management or in political campaigns"56 has resulted in rules for employee behavior that often draw indistinct lines between prohibited and permitted activity. For example:

* Employees may run for office in nonpartisan elections but may not be candidates in partisan elections or for party office. ${ }^{57}$ Thus a federal employee may run for city council in a city where elections are nonpartisan but not in a city where similar elections are held on a partisan basis.

* Employees may make political financial contributions but may not solicit, receive, or disburse such contributions. ${ }^{58}$ An AFGE member can therefore contribute to the union's political action committee but may not urge other members to make such contributions.

* Participation in the nonpartisan activities of civic organizations or unions is permitted, but employees may not participate in such a group's partisan activities. ${ }^{\text {s9 }}$

* Employees may privately or publicly express their opinions on political matters and may display political buttons or stickers. ${ }^{60}$ They may not, however, endorse partisan candidates in "a political advertisement, a broadcast, campaign literature, or similar material."'61

The application of these proscriptions is complicated by the authority given to federal agency heads to further prohibit employee activities if "participation in the activity would interfere with the efficient performance of official duties, or create a conflict or apparent conflict of interests." ${ }^{\text {"82 }}$ Agency management's power to promulgate agency-specific proscriptions thus leaves some federal employees with even less freedom of political participation than is permitted by the Hatch Act. While the authority to tailor restrictions to the sensitivity of certain federal jobs allows greater management flexibility in meeting the particular demands of an agency's mission, recent cases demonstrate that this authority is sometimes abused. The Veterans Administration, for example, issued a policy prohibiting all employees from wearing political

(1984) [hereinafter Developments].

sB 5 U.S.C. \& 7324(a)(2) (1982).

o7 See 5 G.F.R. \$\$ 733.111(a)(10), 733.122(b)(1), 733.122(b)(6) (1986).

${ }^{58}$ See 5 C.F.R. $\$ \S 733.111(\mathrm{a})(8), 733.122(\mathrm{~b})(3)$ (1986).

oo See 5 C.F.R. $\S \S 733.111(\mathrm{a})(4), 733.122(\mathrm{~b})(1)-(16)$ (1986); see also In re Kanemori, 1 P.A.R. 682 (1954) (Kanemori, a postal clerk who represented his union on a local labor council and who was free to engage in most of the council's activities, was prosecuted when his name appeared, as a council member, on a list of laborendorsed partisan candidates.).

bo See 5 C.F.R. §§ 733.111(a)(2), (3) (1986).

61 5 G.F.R. $\$ \S 733.122(b)(10)$ (1986). For similar summaries of Hatch Act restrictions based on these provisions, see Developments, supra note 55, at 1653; Note, supra note 23 , at $170-71$.

62 5 C.F.R. § 733.111(b) (1986). 
buttons $^{63}$ although display of such buttons is clearly allowed by the Act. $^{64}$ In 1984, the Postal Service barred federal employee unions from carrying on voter registration drives, although the unions planned to register voters on a nonpartisan basis. ${ }^{65}$

While extrastatutory contractions of employee rights instituted by agencies often serve to limit political endorsements more severely than the Hatch Act provides, the most serious chill on group endorsements is produced by the official Hatch Act interpretations issued by the Civil Service Commission and the Merit Systems Protection Board. In determining whether an employee statement (for example, "Candidate Doaks should be elected to Congress") is protected opinion or prohibited political activity, the critical issue is whether the employee "with deliberation and as part of a concerted political action, has sought the election or defeat of political candidates." The "concerted political action" requirement is satisfied by a showing that the employee either acted in concert with any political party or took actions that were part of an organized activity for or against a political party. ${ }^{67}$ In cases before the Merit Board, concerted political action has been interpreted to include the publication of a single letter or article in a union newsletter endorsing or opposing a partisan candidate. ${ }^{68}$ Though the employee may believe her article recommending candidate Doaks is a "permissible expression of personal opinion," under the Hatch Act. ${ }^{70}$ Individual employees thus are effectively prohibited from communicating the partisan positions of their organizations through vehicles such as group publications or other traditional media. $^{71}$ 1984).

See American Fed'n of Gov't Employees v. Pierce, 586 F. Supp. 1559 (D.D.C.

o4 See 5 C.F.R. § 733.111(a)(3) (1986) ("Each employee retains the right to- . . . (3) Display a political picture, sticker, badge, or button.").

${ }^{65}$ See American Postal Workers v. United States Postal Serv., 764 F.2d 858

(D.C. Cir. 1985), cert. denied, 106 S. Ct. 792 (1986).

Bo Wilson v. Civil Serv. Comm'n, 136 F. Supp. 104, 106 (D.D.C. 1955).

B7 Id.

${ }^{68}$ See, e.g., Special Counsel v. Clause, 26 M.S.P.R. 556 (West 1985); Special Counsel v. Tacker, 10 M.S.P.B. 452 (1982). See generally Brief of Petitioner at 39, Special Counsel v. Biller, No. HQ12068610018 (M.S.P.B. Oct. 22, 1985) (citing precedents for Hatch Act prosecutions based on employee political endorsements).

69 Tacker, 10 M.S.P.B. at 453.

${ }^{70}$ See id.

${ }^{71}$ In private sector contexts, such restrictions on internal communications among union members raise constitutional problems. See, e.g., United States v. GIO, 335 U.S. 106, 131-32 (1948) (Rutledge, J., concurring). A prohibition on "the publication, by . . . unions in the regular course of conducting their affairs, of periodicals advising their members ... of danger or advantage to their interests from the adoption of measures, or the election to office of men espousing such measures" would raise "the grav- 
Employees acting as representatives of organizations such as unions are given no dispensation to speak on behalf of their organizations. As the Civil Service Commission held in In re Hardman, ${ }^{72}$ "[I]ndividual political activity within a union is as much a violation of law as the same activity anywhere else."73 Moreover, according to a 1984 Special Counsel advisory opinion, a partisan political endorsement by a union converts the union into a "partisan club for the duration of the campaign." union member activities that are normally considered nonpartisan, such as voter registration drives. ${ }^{\mathbf{7 5}}$

The prosecutions of Blaylock, Biller, and Sombrotto-as well as any other federal employee who makes a partisan endorsement-are therefore proper applications of the Hatch Act as currently interpreted. Severe restrictions on endorsements by employees representing group or individual interests are undeniably a prominent feature of current law, but, as the following part contends, they are not a feature justified by the historic purposes of the Hatch Act.

\section{Governmental Interests in Restricting Employee} Political Activity and the Employee Group Endorsement

The governmental interests supposedly served by the Hatch Act are identified by the Supreme Court in Civil Service Commission $v$. National Association of Letter Carriers. ${ }^{78}$ In Letter Carriers, the Court found that the Hatch Act restrictions on political freedom were justified by the federal government's "obviously important interests"77 in limiting partisan political activities by employees. This part examines those interests, as formulated by the Letter Carriers Court, ${ }^{78}$ in an

est doubt ... as to its constitutionality." Id. at 121.

721 P.A.R. 335 (1948).

7s Id. at 342 .

74 Advisory opinion of the Office of Special Counsel, April 6, 1984, quoted in American Fed'n of Gov't Employees v. O'Connor, 589 F. Supp. 1551, 1553 (D.D.C.), vacated, 747 F.2d 748 (D.C. Cir. 1984), cert. denied, 106 S. Ct. 279 (1985). The Special Counsel issues advisory opinions concerning Hatch Act interpretations to federal employees and other interested parties. See 5 U.S.C. $\S 1206$ (1982).

75 The question of whether federal employee unions that endorse partisan candidates may sponsor voter registration drives without violating the Hatch Act remains unsettled. See, e.g., American Fed'n of Gov't Employees v. O'Connor, 747 F.2d 748 (D.C. Cir. 1984), cert. denied, 106 S. Ct. 279 (1985).

${ }^{78} 413$ U.S. 548 (1973). Letter Carriers reaffirmed the holding of United Pub. Workers v. Mitchell, 330 U.S. 75 (1947), which was an earlier challenge to the constitutionality of the Hatch Act.

${ }_{77} 413$ U.S. at 564; see also Mitchell, 330 U.S. at 99 (identifying government interests).

${ }^{78}$ The Letter Carriers formulation is an appropriate framework for two reasons. 
attempt to demonstrate that they do not justify restrictions on employee group endorsements.

The plaintiffs in Letter Carriers, ${ }^{79}$ as class representatives of all federal employees, complained that section 9(a) of the Hatch Act ${ }^{80}$ was unconstitutional on its face and sought an injunction against its enforcement. ${ }^{81}$ A divided three-judge district court panel agreed, finding the statute "impermissibly vague and overbroad when measured against the requirements of the First Amendment . . . ." Inz In granting certiorari, the Supreme Court limited its consideration to "the single question whether the prohibition in section 9(a) of the Hatch Act . . . against federal employees taking 'an active part in political management or in political campaigns' is unconstitutional on its face." ${ }^{\text {"8s }}$ The first amendment rights of federal employees to participate in partisan politics thus were clearly pitted against the federal government's interests in maintaining Hatch Act restrictions. ${ }^{84}$

The Letter Carriers Court found four government interests served by Hatch Act restrictions. First, federal employees "should administer the law in accordance with the will of Congress, rather than in accordance with their own will or the will of a political party." employees should not "appear to the public" to be making politically influenced decisions, "if confidence in the system of representative Government is not to be eroded . . . ."86 Third, employees "should not be

First, the government interests identified by the United States Supreme Court are part of the most authoritative interpretation of the Act. Second, the decision provides an accurate summary of the arguments of courts, commentators, and members of Congress in favor of government employee political activity restrictions. See, e.g., Vaughn, supra note 24, at 527 (arguing that Letter Carriers accepts the "principle of political neutrality ... as a basic characteristic of public employment").

70 The plaintiffs in Letter Carriers were the National Association of Letter Carriers, an AFL-CIO affiliated federal employee union, and six federal employees. Although several political committees sought to challenge the application of the Hatch Act restrictions to state and local government employees under 5 U.S.C. $\$ \S$ 1501(a)(5), 1502(a)(3) (1982), those restrictions were relaxed in 1974. See supra note 25. The district court refused to certify the political committees as class representatives of state and local employees. See National Ass'n of Letter Carriers v. Civil Serv. Comm'n, 346 F. Supp. 578, 579 n.1 (D.D.C. 1972), rev'd, 413 U.S. 548 (1973).

so 5 U.S.C. $\S 7324(\mathrm{a})(2)(1982)$.

81 See 413 U.S. at 551 .

82346 F. Supp. at 585 . The injunction sought by plaintiffs was granted, but a stay was issued pending determination of the case by the Supreme Court.

83 U.S. at 550 .

st The Court addressed the first amendment issue by applying the balancing test established in Pickering v. Board of Educ., 391 U.S. 563, 568 (1968) (requiring a balance between "interests [of employees] in commenting upon matters of public concern," and the interests of government as an employer "in promoting the efficiency of the public services it performs through its employees").

B5 413 U.S. at $564-65$.

86 Id. at 565 . 
employed to build a powerful, invincible, and perhaps corrupt political machine." invitation to vote in a certain way or perform political chores in order to curry favor with their superiors rather than to act out their own beliefs."

The Court unhesitatingly held that these four interests overcame any employee first amendment interest in political participation. ${ }^{80}$ Thus it is settled, at least for now, that a federal employee union member can be constitutionally punished under section 9(a) for endorsing a partisan candidate's election. ${ }^{80}$ This begs the question, however, of whether restrictions on such endorsements are necessary to the maintenance of the governmental interests explicated in Letter Carriers. If no such necessity exists, the prohibition of endorsements is not justified by the rationale validating other Hatch Act restrictions.

\section{A. Nonpolitical Administration of the Law}

The modern civil service system, which stresses a politically neutral method of hiring and retaining federal employees ${ }^{91}$ as the key to fair administration of law, is the product of an intensely political struggle. ${ }^{92}$ In the late nineteenth century, the patronage, or "spoils," system of federal hiring, which based employment decisions on explicitly political grounds, was fiercely attacked by reformers, business people, and some government officials. ${ }^{\theta 8}$ The spoils system made federal jobs no more than plums for politicos who landed on the winning side of the most recent election and resulted in massive changes in government personnel every time a different party came into control of the White House. $^{84}$

87 Id.

88 Id. at 566 .

89 It is interesting to note that while the Court carefully detailed and examined the government interests, the employee side of the balance essentially remained unexplored. See 413 U.S. at 564-67; see also Developments, supra note 55, at 1766 (noting that the Court "did not even touch on the employees' interest" in Letter Carriers).

90 Persuasive arguments have been made that, in light of other decisions of the Court, Letter Carriers was wrongly decided. See, e.g., Developments, supra note 55, at 1654-60.

91 See 5 U.S.C. $\$ 2301$ (b)(1) (1982) ("[S]election and advancement" of federal employees "should be determined solely on the basis of relative ability, knowledge, and skills, after fair and open competition which assures that all receive equal opportunity.").

${ }_{92}$ See Rosenbloom, Politics and Public Personnel Administration: The Legacy of 1883, in Centenary Issues of the Pendleton Act of 1883, at 1, 2 (D. Rosenbloom ed. 1982).

93 See Vaughn, supra note 24 , at 533-39.

24 See id. at 534-35. 
As the importance of government action increased, and the inefficiency of the spoils system grew more disturbing, a reform movement developed, ${ }^{95}$ pitting two strong competing traditions in American politics against each other. ${ }^{88}$ On one side were the politicians who, in the tradition of Andrew Jackson, saw government primarily as a vehicle for responding to the political choices of the electorate. ${ }^{97}$ It simply would not do, argued the proponents of patronage, to make the supporters of defeated policy the administrators of a new regime. When the people speak on election day, the entire government should change according to their wishes. Just as a new president has the right to replace her predecessor's cabinet, so should she be allowed to fill lower offices with those friendly to her policies. ${ }^{88}$

On the other side of the debate were the reformers, who brought a dramatically different view of government to the debate. They emphasized the inefficiency of frequent overhauls of the federal services, and the political corruption that was likely to follow when a ward heeler took control of a federal agency. ${ }^{99}$ Government could not afford the incompetence of the federal employee whose only job qualification was her ability to mobilize her precinct on election day. Moreover, the reformers claimed, patronage discouraged intelligent, dedicated people from entering the federal service. Who would dedicate her career to government work when the next election might put her out of work indefinitely ${ }^{100}$ A government staffed by experienced professionals, it was hoped, would lead to a competent and unbiased federal service that could be trusted with the increasingly important decisions made by the federal government. ${ }^{101}$

The triumph of reform came with the passage of the Civil Service Act of 1883, popularly known as the Pendleton Act. ${ }^{102}$ While allowing

${ }^{95}$ See Developments, supra note 55, at 1626-28.

26 See id. at 1619.

97 See id. at 1624; Rosenbloom, supra note 92, at 3.

${ }^{88}$ See Rosenbloom, supra note 92, at 3. ("[P]atronage hiring and dismissal promoted social and political representation within the federal service. It also enhanced control of the government's administrative component by political authorities, who were not hampered by restrictive rules in hiring, firing, and assigning personnel."). n.50.

92 See Vaughn, supra note 24, at 534; Developments, supra note 55, at 1626

100 See Rosenbloom, supra note 92, at 3-4.

101 See Vaughn, supra note 24, at 534-35, 536-37. Reformers were later disappointed in merit selection as the sole protector of government professionalism. See Developments, supra note 55 , at $1629-30$.

102 See An act to regulate and improve the civil service of the United States, ch. 27, 22 Stat. 403 (1883) (codified as amended at 5 U.S.C. $\$ \S 1101-1105,1301-1303$, $2102,3302-3307,3318-3322,3361,7152,7321,7322,7352$ (1982 \& Supp. III 1985); 40 U.S.C. $§ 42$ (1982 \& Supp. III 1985)). 
the president to retain control of policymaking positions, ${ }^{103}$ it created a "classified" civil service. ${ }^{104}$ Hiring for the service would be based on "open, competitive examinations for testing the fitness of applicants ...."10s The Civil Service Commission was created to establish personnel rules and administer the Act. ${ }^{108}$ Forced payments to politicians-the "assessments" that were the lifeblood of the patronage system-were banned. ${ }^{107}$ The Civil Service Act created the regime that the reformers had called for: federal employees would be hired according to ability and fired only according to rules set by the Commission.

This "merit system" of federal civil service remained virtually unchanged until the passage of the Civil Service Reform Act of 1978. ${ }^{108}$ This Act was primarily a response to charges by federal personnel managers, politicians, and the public that the civil service system had "grown into a bureaucratic maze." 109 President Carter made civil service reform one of his principal campaign pledges, ${ }^{110}$ and the resulting legislation was hailed as "the most comprehensive reform of the Federal work force since the passage of the Pendleton Act in 1883."111 While it made many structural and procedural changes in civil service law, ${ }^{112}$ the principle of nonpolitical hiring and retention that was so

103 See Vaughn, supra note 24, at 539.

104 See An act to regulate and improve the civil service of the United States, ch. $27, \S 2,22$ Stat. 403, 403-04 (1883) (codified as amended at 5 U.S.C. $§ 3304$ (1982)) (empowering the Givil Service Commission to arrange jobs in "classes" whereby examinations would apply to all positions in the class).

205 Id. at 403.

108 See id.

107 The Civil Service Act prohibited federal officers and employees from soliciting or receiving "any assessment, subscription, or contribution for any political purpose whatever." Id. at ch. 27, 11,22 Stat. at 406 . Assessments from beneficiaries of patronage to their elected employers allowed political parties to maintain formidable campaign funds for future elections. Employees were expected to contribute to their party as a condition of government employment.

108 Pub. L. No. 95-454, 92 Stat. 1111 (1978) (codified in scattered sections of 5, $10,15,28,38,39$, and 42 U.S.C. (1982)). See supra note 54. 1978).

100 Carter, 1978 State of the Union Message, 1978 Pub. Papers 90 (Jan. 19,

110 Carter's 1976 campaign attacks on the federal bureaucracy were echoed by members of Congress. The legislative history of the Civil Service Reform Act expresses a deep dissatisfaction with the existing civil service system. See, e.g., S. REP. No. 969, 95th Cong., 2d Sess. 1, 3 (1978), reprinted in 1978 U.S. CodE Cong. \& ADMIN. NEws 2723,2725 ("[T] help to dedicated Federal employees. . . . The public is ill served by the existing civil service system.").

111 Id. at 1, reprinted in 1978 U.S. Code Cong. \& ADMIN. NEws 2723, 2723.

112 For a survey of the changes in agency management and personnel policies that were part of the Civil Service Reform Act see Developments, supra note 55, at 163250. See generally Legislating Bureaucratic Change: The Grvil Service ReFORM ACT OF 1978 (P. Ingraham \& C. Ban eds. 1984) (surveying purpose and effect of CSRA). For analyses focusing on the Act's changes in federal labor-management 
important to the early civil service reformers was preserved ${ }^{113}$ and strengthened. ${ }^{114}$

This historical background of the merit system is important to the analysis of nonpolitical administration of the law and endorsements because it clarifies the role that civil service employees are supposed to play in the federal system. The triumph of civil service reform was a victory for the reformers' vision of the competent and fair public servant as a nonpolitical administrator of the law. ${ }^{116}$ The Hatch Act restrictions on employees as officeholders, candidates, or campaign managers buttress this model. ${ }^{118}$ A politically motivated public administration is positively discouraged, and, as a general matter, if a federal employee does her job competently-i.e., administers her program or carries out her duties according to congressional and agency directives-her employment is statutorily protected. ${ }^{\mathbf{1 1 7}}$

A candidate endorsement by an employee group does not change

relations, see Cooper \& Bauer, Federal Sector Labor Relations Reform, 56 CHI. [-]KENT L. REv. 509 (1980); Smith \& Wood, Title VII of the Civil Service Reform Act of 1978: A "Perfect" Order?, 31 Hastings L.J. 855 (1980).

113 The Senate report on the Civil Service Reform Act, see supra note 110, emphasizes that, while the legislation aims to make comprehensive changes in federal management policies, it also affirms Congress's commitment to a nonpolitical, meritbased civil service. See S. REP. No. 969, 95th Cong., 2d Sess. 1, 1-4 (1978), reprinted in 1978 U.S. Code Cong. \& Admin. News 2723, 2723-26.

114 In addition to codifying a set of "merit system principles," see 5 U.S.C. $\S 2301$ (1982), characterized by one observer as "a lofty 'constitutional preamble' to the law of federal employment," Developments, supra note 55, at 1633, the Civil Service Reform Act created the Office of Special Counsel, see 5 U.S.C. § 1206 (1982), which is responsible for investigating violations of merit system principles, see Developments, supra note 55, at 1643, and prosecuting cases before the Merit Systems Protections Board, see 5 U.S.C. $\$ \S 1205-1208$ (1982), which was created in response to charges that the Civil Service Commission could not fairly adjudicate claims against its own rules and regulations, see Developments, supra note 55, at 1635.

115 The triumph of civil service reform is not universally accepted as a guarantee of "better" government. Some argue, as does Rosenbloom, see supra note 92, that political discretion in hiring and firing promotes government responsiveness to citizen interests. Indeed, the history of federal employment policy may best be viewed as "an ongoing process of competition" between the ideal of political discretion and the ideal of statutory constraints on executive power over employees. See Developments, supra note 55 , at 1620 . Moreover, the goal of nonpolitical federal administration was not fully realized because several Presidents attempted to circumvent the civil service system when pursuing their political policy goals. See Vaughn, supra note 24, at 539-47. The Givil Service Reform Act itself reflects the continuing tension between discretion and constraint; while merit system protections were strengthened, agency managers were given additional discretionary powers. See Developments, supra note 55, at 1633-50.

${ }^{116}$ See Vaughn, supra note 24, at 547-48.

117 The Civil Service Reform Act addresses employee job tenure concerns by "generally prohibiting arbitrary, personally motivated, and politically coercive treatment and by specifically proscribing removal or other reprisals based on employees' disclosure of agency wrongdoing or mismanagement." Developments, supra note 55, at 1634 (footnotes omitted). See 5 U.S.C. § 2301(b)(8)(A), (b)(9) (1982). 
this incentive structure. For example, hypothetical employee union member Jones believes, as do most of her fellow union members, that recent cuts in her agency's budget are unjustified. Presidential candidate Doaks promises to restore funding if elected and Jones' union endorses her. Though Jones may support her union's stand, any attempt to obstruct the operation of her agency on that basis would justify her suspension or dismissal. ${ }^{118}$ The merit system structure is a shield against political dismissals, but it also serves as a sword to be used against employees who fail to carry out their responsibilities.

Some would argue that the real danger of endorsements-or any employee political activities-is that they can lead to more subtle forms of bias. For the political activist, the blurry line between the "appropriate exercise of discretion under the law and political expediency"119 is in danger of disappearing. If an employee maintains partisan political affiliations, loyalty to the impartial administration of the law may yield to political loyalties or ambitions. The only way to combat such bias, it is argued, is to remove the employee from the political fray. ${ }^{\mathbf{2 2 0}}$

These arguments have a powerful appeal. The thought of politically unaccountable public employees subverting the national policy to achieve their own political goals is intuitively contrary to the idea of fair administration of the law, and the idea of employee-politicians cutting political deals for public benefits is patently outrageous. The Hatch Act restrictions on employees running for partisan office and assuming roles in campaigns that make them part of a drive for financial contributions diminish the possibility of such abuses. These restrictions thus appear to be logical measures in the effort to ensure fair administration of the law. ${ }^{121}$

In the case of prohibiting employee endorsements, however, the fair administration argument is less persuasive. The argument misapprehends the dangers inherent in employee expression and calls for a bar on activity that presents no threat to unbiased application of the

118 See, e.g., Nagel v. Department of Health and Human Serv., 707 F.2d 1384, 1387 (Fed. Cir. 1983) ("[F]ailure to perform assigned duties [because of disagreements with management] clearly justifies adverse agency action . . . ."); Shaw v. United States Gov't Printing Office, 26 M.S.P.R. 664 (West 1985) (Penalty of removal from employment for refusal to accept work assignments is within the bounds of reasonableness.); Rose v. Department of Housing and Urban Dev., 26 M.S.P.R. 356, 360 (West 1985) ("Government employees may not refuse an instruction to do certain work merely because they challenge its propriety.").

11 Vaughn, supra note 24, at 548.

120 See id. at 548-50.

121 See R. Dwoskin, supra note 23, at 146 (arguing that while most Hatch Act restrictions are unnecessary, prohibitions on employees running for office or acting as campaign treasurers are needed to avoid conflicts of interest). 
law. If an individual uses a government job to advance personal political goals such as fundraising or running for office, then the conflict of interest is indisputable. ${ }^{122}$ Such an exploitation of position is different in kind from the situation where an employee publicly expresses a partisan political opinion or is associated with a group that expresses such an opinion.

The employee who publicly expresses a partisan political opinion is no more dangerous to fair administration than an employee who remains quiet. ${ }^{123}$ As one commentator has noted, "[I]f a person's job as a civil servant is to be affected because of his ideological slant, such job will be affected whether or not the person is active in venting his views in a political forum." 124 As far as fair administration of the law is concerned, the critical question is whether political opinions lead to the abuse of employee discretion, not whether such opinions are aired publicly. As long as an employee is not abusing her job, the goal of fair administration of the law is not furthered by the imposition of sanctions for the venting of beliefs already held. ${ }^{125}$

\section{B. Public Confidence in Government}

In Letter Carriers the Court held that the appearance of impartial administration of the law is critical if the public's "confidence in the system of representative Government is not to be eroded to a disastrous extent."126 In some respects the use of "public confidence" as a weight in the Court's balance is dubious. The Court does not explain the relationship between public confidence and the specific Hatch Act provisions that it upholds and presents no evidence that confidence is any lower where political activity restrictions are less stringent. ${ }^{127}$ As a

122 See id.

123 See id.; see also Vaughn, supra note 24, at 539 ("Public employees, of course, are not completely impartial because their backgrounds create perspectives that may affect the administration of programs.").

${ }^{124}$ See R. Dwoskin, supra note 23, at 154.

${ }^{225}$ Of course, if an employee measurably changes her job performance in a way that obstructs the management of her agency, she can be punished for insubordinate behavior. See, e.g., cases cited supra note 118.

128413 U.S. at 565.

127 Several states have adopted political activity restrictions for state employees that are much less stringent than those of the Hatch Act. Many allow political activity during nonwork hours on the condition that such activity does not interfere with employee job performance. See Ala. Code § 36-26-38(a) (1985); ARK. Stat. AnN. § 83-119 (1983); Cal. Gov't Code § 3207 (West 1986); ConN. Gen. STAT. § 5266(a) (1985); Del. Code ANn. tit. 29, § 5954(b) (1984); Fla. Stat. $\S 110.233(4)$ (a) (1985); ILL. REv. STAT. ch. 241/2, para. 38(t) (1985); IND. CodE $§ 4-$ 15-2.5-6 (1985); Iowa Code § 19A-18 (1985); Mich. CoMP. Laws § 15.403-.406 (1985); Minn. STAT. § 43A.32(I) (1986); MONT. CoDE ANN. § 13-33-226(3) (1985); 
weight on government's side of the balance, public confidence is difficult to quantify and the assertion of its absence is impossible to rebut. ${ }^{128}$ It adds little to the clarity of the analysis of whether employee political activity restrictions are proper public policy.

In addition, to the extent that public confidence can be gauged by the public's reaction to federal employee political action, the employees are at somewhat of a disadvantage. Normally there will be some measure of public opposition to employee demands for salary increases, pension benefits, or any other changes that will increases taxes, enlarge deficits, or divert public funds from popular programs. ${ }^{129}$ Thus public distaste for federal employee union political positions should be separated from general questions of confidence in government.

Public confidence in fair administration of the law is arguably most shaken by two types of activity. The first is when government power and largesse are used for overtly personal or political reasons. To take a contemporary example, the public was disgusted generally by the revelations of President Nixon's use of executive power to ensure his 1972 reelection and to damage "enemies" of his administration. 1 " The Nixon administration channeled federal funds to help political allies. ${ }^{131}$ It also attempted to politicize the federal personnel system, ${ }^{132}$ using its control over federal agencies to, as one internal memorandum uncovered in the Watergate hearings noted, "utilize resources for maxi-

Neb. Rev. Stat. \& 81-1315 (1985); N.J. Stat. ANN. § 11:17-2 (West 1985); N.M. Stat. ANN. \$ 10-9-21(F) (1985); N.C. GeN. Stat. § 126-13 (1985); N.D. Cent. CODE \& 44-08-19(1) (1985); WIS. STAT. § 230.40(1) (1985). For citations to other state employee political activity statutes, see Developments, supra note 55, at 1659 n.68. No evidence has ever been presented that public confidence in government is diminished in these jurisdictions by relaxed political activity restrictions. In fact, relaxation of restrictions appears to be the trend in the states. See Roumell, supra note 25, at 396 ("On the state level, there is clear evidence of a definite movement toward allowing full expression of political freedom by public servants, as long as it is divorced from the employment setting.").

${ }^{128}$ The analysis of "public confidence" is further muddled by the fact that, in some contexts, public employee expression is essential to the public interest. This is the case with whistleblowers, who publicly expose government fraud or mismanagement. See Vaughn, Statutory Protection of Whistleblowers in the Federal Executive Branch, 1982 U. Ill. L. Rev. 615 (describing Civil Service Reform Act protections for whistleblowers). While an endorsement is obviously not whistleblowing, it can reveal issues and open them up for public debate. While the value of such statements as a part of political discourse is certainly questionable, it is likewise highly improbable that they undermine "public confidence" in representative government.

129 See Summers, Public Sector Bargaining: Problems of Governmental Decisionmaking, 44 U. Cin. L. REv. 669, 673 (1975).

${ }_{130}$ See Apple, A Tragedy in Three Acts, in The End Of A Presidency 28 (1974).

131 See Vaughn, supra note 24, at 531.

132 See id. at 543-44. 
mum political benefit."1ss

The second type of abuse that typically raises citizen ire is the use of a public position to influence or coerce recipients of public services. When a regulatory inspector states that she believes Doaks should be elected senator during the course of an industrial facility inspection or a Social Security worker gives a lecture on the importance of working on the Doaks campaign to a recipient seeking an adjustment in benefits, the plant manager or Social Security beneficiary will surely question the impartiality of the employee's determinations regarding her case.

In both these situations, the legitimacy of government is questioned because of the public servant's willingness to use her position of power to achieve political ends. The employee group endorsement presents a different case. It is made outside of the work environment, and it does not attempt to influence discrete, individual uses of public power or tax money. No exercise of governmental power is involved. The endorsement is rather a general exhortation to abandon or maintain certain officeholders and policies. The public is accustomed to hearing the views of various interest groups through their endorsements. It is likely that citizens would digest a federal employee group endorsement just as they do the preferences of society's multifarious lobbies.

\section{G. The Danger of Machine Politics}

The civil service reformers were concerned not only about the threat to public administration of the law posed by the spoils system but also by the effects of patronage on the political system. One reformer saw the spoils system as creating "a mercenary political class, an oligarchy of stipendiaries, a bureaucracy of the worst kind, which controls parties with relentless despotism."194 The use of federal jobs as rewards for political service and the concomitant assessments paid by employees to their employer's campaign fund were indeed the essential tools for building expansive political machines. ${ }^{135}$ Such machines, which provided incumbents a ready campaign staff of thousands, put opposition parties at a distinct disadvantage, often leading to the distor-

13s Id. at 544 (quoting Memorandum from F. Malek to H.R. Haldemann, Dec. 23, 1971, Malek Exhibit No. 5, reprinted in Hearings on $S$. Res. 60, Watergate and Related Activities, Use of Incumbency-Responsiveness Program Before the Senate Select Comm. on Presidential Campaign Activities, 93d Cong., 2d Sess. bk. 18, at 8230 (1974)).

134 Rosenbloom, supra note 92, at 73 (quoting reformer George William Curtis).

138 See supra note 107. 
tions in the political process decried by the reformers. ${ }^{136}$

The Hatch Act restrictions on working in campaigns effectively shut down such machines. The key to machine politics is manpower: a disciplined regiment of blockwalkers, phone callers, and precinct organizers must be available if the machine is to function effectively. ${ }^{137}$ Mere expressions of support do not get the voters out on election day. ${ }^{138}$ Allowing federal union endorsements would not create the danger articulated by the Letter Carriers Court that a political party could use "the thousands or hundreds of thousands of federal employees, paid for at public expense, to man its political structure and political campaigns."1s9

In addition to the practical difference between an endorsement and an order to work in a campaign, another factor militates against the danger that employee endorsements will create political machines. Federal employee groups, unlike patronage beneficiaries, are not tied to the policies of incumbents. They have no vested interest in perpetuating an incumbency if the incumbent's policies are hostile to employee interests, and will instead endorse candidates based on perceived employee needs. Moreover, the merit system removes incentives for political participation on behalf of incumbents by making it irrelevant to employee advancement in the federal service. Employee groups, as the voice of employees rather than an arm of the party in power, will speak more independently than the spoils recipient struggling to keep her job. ${ }^{140}$ The recent history of federal union endorsements illustrates this point: of the three presidential endorsements made by the AFGE, two have been in favor of challengers rather than for incumbents. ${ }^{141}$ Similarly, the now defunct Professional Air Traffic Controllers Organization en-

196 In the Civil Service Act debates of 1883 , Senator Pendleton went so far as to claim: "I believe that . . . the 'spoils system' must be killed or it will kill the Republic." Vaughn, supra note 24 , at 535.

137 See L. SaBATO, supra note 22, at 199 (pointing out that even in the modern, media-intensive political campaign, political organization and volunteers remain extremely important).

138 See supra note 22.

139413 U.S. at 565-66.

140 Some argue that public employee union political involvement would be helpful in protecting the merit system against attacks by incumbents or challengers. The unions "can be effective checks on the exploitation of public employees for political purposes and the spoils system." Minge, Federal Restrictions on the Political Activities of State and Local Employees, 57 MinN. L. REv. 493, 538 (1973) (footnote omitted).

141 In 1976, the American Federation of Government Employees (AFGE) endorsed Jimmy Carter in his challenge to President Ford. In 1980, the AFGE endorsed President Carter's reelection. In 1984, the AFGE endorsed challenger Walter Mondale over President Reagan. See OSC Accuses Three Union Chiefs of Unlawful Political Activity, supra note 17. 
dorsed challenger Reagan over incumbent Carter in $19800^{142}$

\section{The Danger of Coercion}

Any attempt to assess the danger of coercion in a large organization such as the federal government is inherently inexact for two reasons. First, coercion is difficult to objectify. As a former chairman of the Civil Service Commission stated, "[O]ne man's coercion is another man's persuasion,"143 and the line between the two often depends on personal proclivities or experiences. Second, "[c]oercion in any large organization based upon a hierarchical structure is difficult to control because it is difficult to detect."144 Subordinates are often eager to conform their behavior to that of their superiors, whether or not conformity is expected. Moreover, much subtle pressure may go unreported to avoid "causing trouble." Nevertheless, because the avoidance of political coercion is a stated goal of the merit system ${ }^{145}$ and is of obvious importance to employees, an analysis of the issue is appropriate to an understanding of whether employee group endorsements should be permitted.

In analyzing the endorsement question, a distinction between the potential for persuasion and the potential for coercion should be established. One can isolate several instances where employees might attempt to persuade one another: group members may be pressured to vote a certain way at an endorsement meeting, dissenting employees may be pressured to support endorsed candidates, or nonmember employees may be pressured to support a group's endorsed candidate. Although there may be several avenues of pressure or persuasion, there are two areas in which the power relationships involved are likely to turn friendly persuasion into coercion. In these situations, a partisan persuader has the power to take job-related actions against an employee based on political affiliations.

First, there exists the possibility of coercion by the union. ${ }^{148}$ As the exclusive bargaining representative for an employee's bargaining unit, the union conceivably could discriminate against a member or nonmem-

142 See Sinzinger, supra note 13.

${ }^{143}$ Vaughn, supra note 24, at 551 n.256 (quoting former Civil Service Commission chairman John Macy).

144 Id. at 551.

145 See 5 U.S.G. \& 2301(b)(8)(A) (1982). ("Employees should be-protected against . . . coercion for partisan political purposes.").

148 Unions should be distinguished from employee benefit associations in this context. Employee associations normally do not have any economic power or other jobrelated power over employees. Unions, when recognized as official bargaining agents, could take discriminatory actions against employees and directl, affect their job status. 
ber ${ }^{147}$ in, for example, representation at grievance proceedings $s^{148}$ if the employee refuses to support an endorsed candidate. If such discrimination occurs, however, the employee can file an unfair labor practice charge against the union under the provisions of the Civil Service Reform Act. ${ }^{140}$ As a practical matter, a federal union would probably hesitate to exhibit such discrimination. Because there are no provisions for union security in the federal sector, ${ }^{180}$ union strength depends primarily on the union's ability to attract large numbers of members. The union simply cannot afford to alienate current or potential members in the federal workforce.

Second, a supervisor may coerce a subordinate. Supervisory coercion may include attempts to coerce a subordinate who is a fellow group member to vote a certain way at the group's endorsement meeting, attempts to convince a dissenter to show support for the endorsed candidate, or attempts to persuade a nonmember to support the group's candidate. ${ }^{151}$ Again, however, remedies for such coercion are available under the Civil Service Reform Act. If supervisory political coercion results in any adverse action against the employee, the employee can charge the supervisor with a prohibited personnel practice, ${ }^{152}$ which could result in the suspension of the supervisor for up to five years and the imposition of fines of up to $\$ 1000 .{ }^{163}$ Moreover, such on-the-job

${ }^{147}$ It is important to note that agency or union shops are not allowed in the federal sector. A union recognized by an agency as an exclusive representative of a bargaining unit must represent "the interests of all employees in the unit . . . without regard to labor organization membership." 5 U.S.C. § 7114(a)(1) (1982).

148 All federal sector collective bargaining agreements must include grievance procedures. See 5 U.S.C. $\$ 7121$ (a)(1) (1982). The limits of grievance procedures are outlined in 5 U.S.C. $\$ 7121$ (1982).

140 See 5 U.S.C. $\& 7116($ b)(4) (1982) ("[I]t shall be an unfair labor practice for a labor organization-... (4) to discriminate against an employee with regards to terms or conditions of membership in the labor organization on the basis of . . political affiliation....").

${ }_{160}$ See supra note 147.

161 The type of supervisor coercion discussed herein would not occur in a union context because supervisors and management officials are barred from union membership. See 5 U.S.C. $\$ 7103$ (a)(2)(B)(iii) (1982) (excluding supervisors and managers from definition of "employee"); id. $\$ 7112(\mathrm{~b})(1)$ (supervisors and managers are not counted when bargaining units are determined). Endorsement-related coercion by supervisors could arise, however, in nonunion employee groups.

132 See 5 U.S.C. $\$ 2302(b)(3)$ (1982). The statute states:

Any employee who has authority to take, direct others to take, recommend, or approve any personnel action, shall not, with respect to such authority - . . (3) coerce the political activity of any person (including the providing of any political contribution or service), or take any action against any employee . . . as a reprisal for the refusal of any person to engage in such political activity.

${ }^{188}$ See 5 U.S.C. § 1207(b) (1982). 
solicitations of political support violate a section of the Hatch Act unrelated to endorsements. ${ }^{154}$

Thus, remedies are available for any employee who is coerced or discriminated against due to her position on an employee group endorsement. Some would argue that such remedies are not as effective as the Hatch Act's outright prohibitions of political advocacy. ${ }^{155}$ In most cases, however, the Hatch Act provides no more significant protection against coercion than the employee-protective sections of the Civil Service Reform Act. ${ }^{158}$ Both the Hatch Act and the Civil Service Reform Act provisions are investigated and prosecuted by the Office of Special Counsel and are heard before the Merit Systems Protection Board. ${ }^{\mathbf{1 5 7}}$ If the Special Counsel is willing to pursue and prosecute coercion charges actively, employees will be protected from coercion regardless of the source of the coercion. ${ }^{168}$ Lifting the prohibition on endorsements would thus appear to have, at most, a negligible impact on the potential for coercion of federal employees.

It is worth noting that if the federal government is serious about preventing coercion of employees, it should provide prophylactic measures and remedial structures aimed more directly at coercion itself. As a prophylactic device, endorsement proscriptions are a rather blunt instrument; they sweep away any opportunity for employee expression regardless of its potential for coercion. A more effective system would aim its prohibitions and penalties at coercion as such, rather than broadly directing them at employee expression.

The foregoing analysis demonstrates that restrictions on employee

164 See 5 U.S.C. $\S 7324(a)(1)$ (1982) (A federal employee may not "use his official authority or influence for the purpose of interfering with or affecting the result of an election....").

18s See, e.g., Vaughn, supra note 24, at 551-53. Vaughn argues that there are basically three problems involved in protecting federal employees from political coercion in the absence of the Hatch Act. He notes first that coercion in a large, hierarchical organization may be difficult to detect. A superior will have a diverse array of penalties to impose, ranging from transfers to changes in the atmosphere of the workplace. Vaughn further asserts that many employees will be unlikely to complain due to fear of reprisals. Finally, Vaughn expresses doubt as to the adequacy of enforcement mechanisms, arguing that any enforcement body that is tied in any way to the President will have questionable efficacy.

${ }^{168}$ Hatch Act violations are penalized by the dismissal of the employee or, if the Merit Board unanimously finds that the violation does not warrant dismissal, suspension of at least 30 days. See 5 U.S.C. $\S 7325$ (1982).

${ }_{187}$ See 5 U.S.C. $\$ \S 1205-1206$ (1982). Federal sector unfair labor practice cases, however, are prosecuted by the General Counsel of the Federal Labor Relations Authority, an agency also created by the Civil Service Reform Act. See 5 U.S.C. $§ 7104$ (1982 \& Supp. III 1985).

${ }^{188}$ Some claim that the Office of Special Counsel has been somewhat ineffective in carrying out its various responsibilities. See Developments, s spra note 55, at 1645 . 
group endorsements are not necessary for the protection of the government interests set out in the Court's opinion in Letter Carriers. Lack of necessity, of course, is not a reason in itself to abandon the endorsement prohibition-it could be viewed as an unnecessary but harmless addition to the battery of restrictions that truly protect federal employees and the merit system generally. There are, however, important employee interests that weigh against the current law. Those interests are the subject of the following section.

\section{Employee Interests, Political Process, and Group ENDORSEMENTS: THE NEED FOR CHANGE}

Federal employee group endorsements should be permitted as a matter of political and labor policy. While the policies behind the Hatch Act as a whole may be sound, the present restrictions on employee endorsements fail to prevent employee political involvement, provide an opportunity for union leaders and the president's political appointees to monopolize the debate on public employment policy, and distort the democratic process by excluding from political conflicts an interest group with high stakes in the outcome of these conflicts.

One must remember that the Hatch Act cannot prevent employee organizations from making endorsements; it only prevents government employees from personally doing the endorsing. So long as non-employees advocate the election of a partisan candidate on behalf of the union, there will be no violation. In the cases arising out of the 1984 Mondale endorsements, for example, Blaylock, Biller, and Sombrotto could be prosecuted because, although each has been on leave without pay for several years, they have retained federal employee status while serving as union presidents. National Federation of Federal Employees president James Pierce, however, is a retired federal employee ${ }^{159}$ and cannot be prosecuted for his efforts on behalf of Mondale. This makes for a rather odd rule: employee groups may advocate the election of partisan candidates, but employees themselves had better not do the talking.

While this rule is usually inconsequential, it may produce rather disturbing results in some contexts. The leader of a large national union can afford to hire a press secretary or similar staff member to present the union's views on partisan candidates, thus keeping union leadership out of trouble. ${ }^{160}$ Union locals and other small employee

159 See OSC Accuses Three Union Chiefs of Unlawful Political Activity, supra note 17 , at 212 .

${ }_{100}$ The largest federal employee unions maintain full-time national staffs consisting of non-federal employees. See Masters, supra note 5, at 618-19. 
groups, however, may not have such resources, and therefore will not have the ability to speak out on matters of local interest, such as congressional elections. More significantly, dissenting voices can be muzzled. While the national organization may have announced support for candidate Doaks through a union staff member, employees who disagree with the Doaks endorsement are unable to say that Cooley is the better candidate. The top levels of union hierarchies thus have greater control over expression of employee interests than do the employees themselves. This could engender the creation of a gulf between the public position of a union and the actual opinions of large groups of government employees who may disagree with the statements of the union's paid spokesperson but who are prohibited by the Hatch Act from personally and publicly registering their dissent.

In addition, while prosecutions for union endorsements cannot eliminate the expression of union candidate preferences, they can serve as a useful tool for inflicting pain on unions opposed to an incumbent administration's policy. If the Office of Special Counsel is inclined to pursue enemies of the administration in power, it can prosecute union members who oppose the administration. ${ }^{181}$ Such prosecutions naturally put the union on the defensive and force it to expend time and treasury funds defending its members. ${ }^{162}$ Although endorsements do not endanger the merit system ${ }^{\mathbf{1 6 3}}$ and no coercion of employees or citizens is demonstrated, the Special Counsel can make a case of a Hatch Act violation, leading to suspension or dismissal of the union employee. Such Hatch Act prosecutions and convictions send a powerful signal to unions to hush their opposition to an incumbent officeholder.

Finally, the Hatch Act endorsement prohibitions unfairly restrict federal employees' ability to speak on matters that ultimately affect basic employee interests. Because of this, it excludes from essentially political conflicts the interest group most concerned with the outcome of these disputes.

Public employment relations are inescapably political. The rate of pay, length of vacation time, and extent of pension benefits received by federal employees are not employment issues of interest only to man-

101 Suspicions that the current Special Counsel is prosecuting on a partisan basis are widespread among union leaders and members of Congress alike. See Sinzinger, supra note 13, at 430 .

${ }^{162}$ In addition, many employees may not be willing to risk their jobs by actively litigating Hatch Act charges. Begging for forgiveness and settling with the Merit Board may be the safest route for many employees. Cf. Special Counsel v. Tacker, 10 M.S.P.B. 452 (1982) (employee settles and promises never to participate in designated activities).

${ }^{163}$ See supra notes $118-25$ and accompanying text. 
agement and labor. They are questions of political policy and involve government decisions about tax rates, budget deficits, and the level of public services. ${ }^{164}$ Decisions regarding terms of employment are shaped by the desire to balance budgets, implement or phase out services, or test disloyalty or substance abuse on the part of public employees. ${ }^{165}$ Moreover, decisions concerning federal employees are political in the sense that "those making the decisions will do in the political market what business men do in the economic market-maximize their gains and minimize their losses."168 The maximization of votes will always guide the elected politicians who ultimately decide the terms of federal employment.

In this political setting, federal employees must be viewed as an interest group with high stakes in the outcome of public decisionmaking. Employees have a substantial stake not only in general questions of wages and benefits but also in decisions concerning the structure and function of the civil service system and the size of their agencies' budgets. ${ }^{167}$ Like welfare mothers, defense contractors, Social Security recipients, and farmers, federal employees are a group that, acting in its own interest, seeks favorable treatment from elected decisionmakers. ${ }^{188}$ The

104 See Summers, supra note 129 , at 672 .

168 See, e.g., Resistance to Reagan's Drug Testing Plan, Christian Sci. Monitor, Sept. 17, 1986, at 3, col. 3 (describing federal employee union efforts to block mandatory drug testing for federal employees); Shapiro, The First Casualties-Gramm-Rudman Ushers in the Un-COLA Era, NewsweEK, Jan. 13, 1986, at 30 (describing impact of Gramm-Rudman budget cuts on federal employee wages); Shultz: A-flutter, NewsweEK, Dec. 30, 1985, at 20 (describing reaction to Reagan administration plans to subject some federal employees to lie-detector tests); N.Y. Times, Nov. 17, 1985, at Al, col. 3 (describing budget deficit pressures on federal employment policies).

${ }_{108}$ Summers, supra note 129, at 672.

167 Employees have a vital stake in maintaining the job security protections that are part of federal service. Cf. Masters, supra note 5, at 620-24 (analyzing employee lobbying efforts during the 1978 congressional debates concerning the Civil Service Reform Act).

${ }^{183}$ See Imundo, Some Comparisons Between Public Sector and Private Sector Collective Bargaining, in Labor Relations in the Public Sector 35, 39 (M. Levine \& E. Hagburg eds. 1979). Though often criticized, active "interest groups" are vital to a properly functioning democracy. Professors Harry Wellington and Ralph Winter note:

Organizations based on mutual economic interests, such as trade associations or labor unions, are paradigms of associations, factions, or-as they are usually called today-interest groups. Such groups are absolutely necessary to the survival of political democracy in the United States. They are the means by which individuals make claims upon government; thus they are important to the structure of our federal system. These groups collect, create, and transmit the economic desires of their members to other interest groups; thus they are vital to political, economic, and social organization.

Many claims made by many interest groups are self-serving and, if 
need to influence politicians is reflected in federal employee unions' lobbying efforts. ${ }^{169}$ The unions lobbied intensively for and against provisions of the Civil Service Reform Act, for pay scales comparable to the private sector, and against caps on wage increases. ${ }^{170}$ As with any organized interest group, employees' success in influencing Congress will depend on the skill of its lobbyists and the prevailing direction of the political winds. ${ }^{171}$ Unlike similar interest groups, however, federal employees do not have the option of publicly exerting electoral pressure on politicians unfriendly to their cause.

As private sector labor unions $\mathbf{1 7 2}^{\mathbf{1 2 2}}$ and other groups have learned, the ability to exert partisan pressure during elections is often critical to the advancement of group interests. While post-election lobbying may produce some benefits, ${ }^{173}$ the effectiveness of such lobbying is often predetermined by the election of a sympathetic or hostile president and members of Congress. If political activity restrictions are needed to protect legitimate government interests, ${ }^{174}$ then denying employees active participation in partisan politics may be justified. No similar justification exists for denying employee input into the debate regarding partisan elections.

Some have argued that, although federal employees have a strong interest in political decisions, they should sacrifice their own interests for the public good. ${ }^{\mathbf{1 7 5}}$ Just as federal employees are not allowed to strike because Congress "has an obligation to ensure that the machinery of the Federal Government continues to function at all times without interference,"178 it is argued that they should be willing to sit out the debate regarding other conditions of employment. These arguments

granted, would be contrary to national welfare. But that is not the point. The point is that unless individuals can freely band together to advocate whatever they please, we shall not have democracy.

H. Wellington \& R. Winter, The Unions and The Cities 72 (1971).

${ }^{108}$ See generally Masters, supra note 5 (analyzing employee lobbying efforts).

170 See id. at 620-27.

171 See id. at 627-28.

${ }^{172}$ Cf. Comment, The Regulation of Union Political Activity: Majority and Minority Rights and Remedies, 126 U. PA. L. REv. 386, 389 (1977) ("Labor organizations now realize that the political arena, as well as the bargaining table, is a crucial forum for their interests.").

17s The Lloyd-LaFollette Act, ch. 389, 37 Stat. 555 (1912) (codified at 5 U.S.C. $\S 7211$ (1982)), sanctions some forms of federal employee lobbying activity. See infra note 177 .

174 See supra notes 91-158 and accompanying text.

175 See Cooper \& Bauer, supra note 112, at 512.

178 United Fed'n of Postal Clerks v. Blount, 325 F. Supp. 879, 884 (D.D.C.) (three judge panel), aff'd, 404 U.S. 802 (1971). The economic power available to federal employee unions is discussed in more detail infra notes 187-99 and accompanying text. 
ring hollow for two reasons. First, although political activity restrictions have long been the rule, Congress has allowed employees to organize and petition for legislative action since the passage of the LloydLaFollette Act of $1912 .{ }^{177}$ Taking a federal job may entail the sacrifice of some political rights, but it has never been the public sector equivalent of entering the priesthood. Second, the argument assumes that policies concerning federal employment are always in the public interest. It is questionable, however, whether federal employment policies such as drug testing for employees ${ }^{\mathbf{1 7 8}}$ and salary discrepancies between the public and private sectors ${ }^{179}$ fall within the public interest rubric, and whether employees affected by them should be unable to enter the debate regarding their efficacy. Public employees have vital and distinct interests that they should not be forced to relinquish because of the character of their employer.

In the case of public sector unions (as distinguished from nonunion employee benefit groups), some commentators have raised the additional argument that allowing both collective bargaining rights and political activity tends to distort normal political processes and thereby diminish democracy. ${ }^{180}$ This argument, usually associated with Professors Harry $\mathrm{H}$. Wellington and Ralph $\mathrm{K}$. Winter, Jr., ${ }^{181}$ expresses the concern that if public employees are given broad collective bargaining rights and can apply traditional forms of electoral pressure, they will possess "a disproportionate share of effective power"182 in the political decisionmaking process.

Public employees, according to the Wellington-Winter thesis, would be on equal footing with other interest groups if they possessed only the power to pressure government-via elections and lobbying-to act in their interest. When public employees are given the right to bar-

177 See Lloyd-LaFollette Act, ch. 389, 37 Stat. 555 (1912) (codified at 5 U.S.C. $\S 7211$ (1982)) ("The right of employees, individually or collectively, to petition Congress or a Member of Congress . . may not be interfered with or denied."). For a discussion of federal employees' rights to petition and lobby, see H. EDWARDS, R. Clark \& G. Craver, Labor Relations law in the Public Sector: Cases and Materials 861-67 (2d ed. 1979).

${ }_{178}$ See Resistance to Reagan's Drug Testing Plan, supra note 165.

179 See Masters, supra note 5, at 624 (discussing proposed revisions of the 1970 Pay Comparability Act).

180 See, e.g., R. Summers, Collective Bargaining and Public Benefit Conferral: A Jurisprudential. Gritique (1976); H. Wellington \& R. WinTER, supra note 168, at 25-30; Clark, Politics and Public Employee Unionism: Some Recommendations for an Emerging Problem, 44 U. CiN. L. REv. 680, 681 (1975); Wellington \& Winter, The Limits of Collective Bargaining in Public Employment, 78 YALE L.J. 1107, 1123 (1969).

181 The argument is most thoroughly explored in their book The Unions and the Cities, see H. Wellington \& R. WINTER, supra note 168 .

182 Id. at 25. 
gain and strike they gain access to a power that no other group possesses: employees can negotiate face-to-face with government for their needs, thus bypassing electoral and legislative processes. ${ }^{183}$ The unions-as a private interest group-can force government officials to negotiate certain issues of public concern and, through political activity, can elect the government officials with whom they negotiate. In this way, public sector unions can, in effect, "sit on both sides of the bargaining table."184 Groups opposing public employee interests have no equivalent power. Employee union power could in this manner permanently tilt the political process in the unions' favor. ${ }^{185}$

Even if the Wellington-Winter thesis is assumed to be valid, ${ }^{186}$ the dangers to democratic processes that it fears would not be present if federal employee unions were given the freedom to make endorsements. The critical assumption of the Wellington-Winter thesis is that public employee unions possess broad collective bargaining rights, including the right to strike. ${ }^{187}$ These economic powers, when combined with political activities, give the unions an inordinate share of power. In the federal sector, however, such power is not available to employee unions.

Although the statutes governing federal sector labor relations ${ }^{\mathbf{1 8 8}}$ give employees the right to join unions and bargain collectively, ${ }^{189}$ those rights are extremely limited. ${ }^{190}$ An extensive management rights clause limits negotiable issues. ${ }^{191}$ Most notably, the determination of an agency's budget is removed from the scope of collective bargaining, ${ }^{192}$ effectively precluding unions from negotiating employee wages. What remains open for negotiation are the "conditions of employment,")

183 See Clark, supra note 180 , at 684.

184 Id.

185 See H. Wellington And R. Winter, supra note 168, at 25.

${ }^{188}$ The thesis has its critics. See, e.g., Cohen, Does Public Employee Unionism Diminish Democracy?, 32 Indus. \& LAB. ReL. Rev. 189, 192 (1979) (Cohen argues that the Wellington \& Winter thesis is not broadly applicable and that empirical counter-examples exist.). In a 1985 article, Professor Masters reports, "[t]he debate over this controversial thesis remains unresolved." Masters, supra note 5, at 613.

187 See H. Weilington \& R. Winter, supra note 168, at 25.

${ }^{188}$ See 5 U.S.C. $\S \S 7101-7135$ (1982 \& Supp. III 1985).

189 See 5 U.S.C. $\S 7102$ (1982) ("Each employee shall have the right to form, join, or assist any labor organization, or to refrain from any such activity, freely and without fear of penalty or reprisal, and each employee shall be protected in the exercise of such right.").

100 See Smith \& Wood, supra note 112 , at 857.

101 See 5 U.S.C. $\S 7106$ (1982).

1925 U.S.C. $\S 7106$ (a) (1982) provides: "[N]othing in this chapter shall affect the authority of any management official of any agency-(1) to determine the mission, budget, organization, number of employees, and internal security practices of the agency."

${ }^{193}$ See 5 U.S.C. $§ 7103(a)(14)$ (1982) (defining "conditions of employment"). 
which are defined as policies affecting only working conditions, ${ }^{194}$ thus precluding negotiations on more substantive personnel policies. Union security shops are not permitted; a union with exclusive representation rights in a bargaining unit must represent all employees regardless of union membership. ${ }^{195}$ Most significantly, there are strong proscriptions on strikes. ${ }^{106}$ An employee who participates in a strike or belongs to an organization which advocates the right to strike is barred from federal employment. ${ }^{187}$ Strikes, work stoppages, and slowdowns are unfair labor practices under the federal labor relations scheme $e^{198}$ and a union that authorizes or allows such activities is subject to decertification. ${ }^{198}$

As one commentator notes, these limits on strikes and the negotiability of labor disputes "reduce the scope of bargaining in the federal sector to boundaries compatible with what Wellington and Winter . . . would recommend."200 The stringent limits on federal union economic power thus diminish the potential danger of inordinate union power feared by Wellington and Winter. Moreover, Hatch Act limitations cut employees out of the action on the political side as well, leaving them in a fundamentally weaker position than that of most interest groups.

Thus, in the case of both union and nonunion federal employees, lifting Hatch Act limitations on endorsements would not skew the political process in favor of employee interests. Rather, it would make for a healthy adjustment in the political process by allowing a group with a vital interest in the electoral process to be heard.

\section{CoNCLUSION}

Removing Hatch Act restrictions on partisan political endorsements may not change the outcome of any given election. ${ }^{201}$ What employee groups say in their endorsements may persuade few, if any, and may even repel some voters. Nevertheless, the removal of the endorsement restrictions would provide a fair and sensible adjustment to the

194 See id. Strict substantive limits are also placed on the legal subjects covered by grievance procedures in collective bargaining agreements. See 5 U.S.C. $\S 7121$ (c) (1982).

${ }_{105}$ See supra note 147.

188 A constitutional challenge to the prohibition of federal employee strikes was rebuffed in 1971. See United Fed'n of Postal Clerks v. Blount, 325 F. Supp. 879 (D.D.C.), affd, 404 U.S. 802 (1971).

${ }_{187}$ See 5 U.S.C. $\& 7311(3)-(4)$ (1982).

188 See 5 U.S.C. $\$ 7116(\mathrm{~b})(7)(1982)$.

100 See 5 U.S.C. $\S 7120(f)(1982)$.

200 Cohen, supra note 186 , at 191.

${ }^{201}$ It would be difficult to argue that the 1984 federal employee union endorsements had any measurable effect on the outcome of the presidential contest between Walter Mondale and President Reagan. 
Hatch Act. It would increase employee political freedom without interfering with the federal government's ability to carry out its duties fairly and efficiently. In addition, it would end the absurdity of making employees who endorse candidates vulnerable to prosecution while allowing non-employee union officials to endorse candidates with impunity.

The change could be easily accomplished. ${ }^{202}$ Moving the endorsement of partisan candidates from the list of activities prohibited under the Act to the list of permitted activities is all that would be necessary. ${ }^{203}$ Congress can make such a change by amending section 9 (a) of the Act. Such an amendment would provide a reasonable compromise between the political rights of federal employees and the need for limits on employee political activity. ${ }^{204}$ Such a compromise would not allow full employee participation in political affairs, but it would at least allow federal employees to be a part of the public debate about "campaigns that may bring about changes in their lives, their fortunes, and their happiness."

202 Although the required adjustment in the statute would be simple, getting congressional approval for such an adjustment may prove more difficult. The Hatch Act, though often criticized, has proved to be extremely resilient. Since 1975, 33 bills have been introduced to amend the Hatch Act, but none has been successful. See Earley, Hatch Act Restrictions Arouse Challenges, Washington Post, April 17, 1984, at A19, col. 2. Another bill seeking to amend the Act was filed in 1985 by Representative William Clay of Missouri. See New Bills Would Amend Hatch Act, Shorten Fire Fighter Work Week, 23 Gov't Empl. Rel. Rep. (BNA) 45 (Jan. 14, 1985). The closest any major reform has come to passing was the Federal Employees' Political Activities Act of 1976. Although it passed in both houses of Congress, the bill was vetoed by President Ford. See Note, supra note 23, at 183.

${ }^{203}$ See supra notes 57-61 and accompanying text.

204 As noted supra note 127, such accommodations have been made in several state public employee political activity statutes.

${ }_{200}$ United Pub. Workers v. Mitchell, 330 U.S. 75, 107 (1947) (Black, J., dissenting). 
